\title{
Crevassing and capture by floodplain drains as a cause of partial avulsion and anastomosis (lower Rio Pastaza, Peru)
}

\section{Carolina Bernal, Frédéric Christophoul, José Darrozes, Alain Laraque, Luc Bourrel, Jean-Claude Soula, Jean-Loup Guyot, Patrice Baby}

\section{Submitted to the Journal of South american Earth Sciences (December-06-2011)}

C. Bernal, F. Christophoul, J. Darrozes, J-C. Soula, A. Laraque, L. Bourrel and P. Baby, UMR 5563 GET, Université de Toulouse CNRS - IRD - CNES, 14 Av, Edouard Belin, F-31400 Toulouse, France

frederic.christophoul@get.obs-mip.fr

\section{Patrice Baby, patrice.baby@ird.fr}

C. Bernal, chavelacarola@yahoo.com.mx

L. Bourrel, luc, bourrel@get.obs-mip.fr

A. larque, alain.laraque@ird.fr

J. Darrozes, darrozes@get.obs-mip.fr

J-C.Soula,ssoula@get.obs-mip.fr

J-L. Guyot, IRD Brasil, CP 7091 - Lago Sul, 71619-971 - Brasilia (DF), Brazil, jean-loup.guyot@ird.fr

\section{ABSTRACT}

Avulsion is the main process at the origin of anastomosing rivers. This study illustrates 3 examples of avulsions resulting from crevasse-splays evolving in anastomosed channels along the Rio Pastaza, a tropical humid river sourced in the Ecuadorian Andean Cordillera and flowing into the Amazonian foreland. The Lower Pastaza flows in an alluvial plain, with no tectonic influence and an average monthly rainfall equally distributed throughout the year. Based on the analysis of satellite image recorded over the period 1977-2008, three cases have been studied. The first one began in 1990 with crevassing of natural levees of the right bank of the Pastaza main channel and the formation of a small stream travelling toward a pre-existing tributary to this main channel. A splay formed at the confluence beheaded the tributary which became an anabranch of the main river. Downstream, two other avulsions developed from ancient crevasse-splays on a low gradient floodplain. In both cases, capture of one of the distributary channels flowing on the splay by a pre-existing drain of the floodplain and consecutive headward erosion arrives to disconnect the other drains and capture their flow into a single thread channel. As this channel rejoins the Pastaza main channel downstream, this process gives rise to the larger-scale anastomosing system which characterizes the lower Pastaza. Although the precipitation regime and discharges curves are rather regular, levees breaching and crevasse splay formations is likely to be a result of annual floods which are present in this area as in the rest of Amazonia.

Keywords: Crevasse-splay, avulsion, anastomosis, Amazonian basin, floodplain, Pastaza.

\section{1 - INTRODUCTION}

Avulsion is the process whereby a channel belt shifts relatively abruptly from one location in the floodplain surface to another in favour of a steeper gradient (Slingerland \& Smith, 2004; Mohrig et al., 2000; Bridge, 2003; Stouthamer, \& Berendsen, 2007). Avulsions may result in a new channel belt (Makaske, 2001).

Avulsions can take place in a variety of alluvial environments, including alluvial fans, braided river floodplains, meandering river floodplains, anastomosed rivers and delta plains (Törnqvist, 1994; Jones \& Harper, 1998; Morozova \& Smith, 2000; Makaske, 2001; Jain \& Sinha, 2005; Leier et al., 2005; Assine, 2005; Sarma, 2005; Sinha et al., 2005). Avulsions are primarily features of aggrading floodplains (Slingerland \& Smith, 2004) where they constitute the main cause of anastomosing channel initiation (Makaske, 2001).

River avulsion setup is a long term process where the river aggrades over tens to thousands of years and becomes poised for avulsion. Several mechanisms have been proposed as being responsible for important aggradation rates including increased sediment load relative to capacity, change in peak water discharge, or decrease in channel gradient owing to sinuosity increase, delta extension, base level perturbation, downstream tectonic uplift (Jones \& Schumm, 1999; Stouthamer \& Berendsen, 2000; Slingerland \& Smith, 2004). The trigger is a short-term event which immediately provokes the avulsion. Triggers are most frequently floods, but could also be processes as varied as abrupt tectonic movements, ice jams, log dams; vegetative blockages, debris dam, beaver dams, hippopotami trails, or other bank failures and downstream migration of bars that temporarily block the throat of a branch (Stanistreet et al., 1993; Jones \& Schumm, 1999; Mohrig, 2000; Slingerland \& Smith, 2004).

It has been suggested that two end-members of the avulsion series could be (1) incisional avulsion characterized by an early incision and then infilling by migrating bar and (2) aggradational avulsion beginning with aggradation followed by integration of streams into a single downcutting channe (Smith et al., 1989). Mohrig et al. (2000) proposed that the type of avulsion is strongly influenced by whether or not the adjacent flood plain is well drained.

Several numerical models of avulsion have been proposed in order to understand mechanics and sedimentary architecture of alluvial plains, deltas, and fans (Slingerland and Smith, 1998; Jerolmack \& Paola, 2007). However, these models do not include some aspects of the 
fluvial environment (e.g., vegetated levees and floodplains) that may play a key role in avulsion dynamics (Mohrig et al., 2000). Indeed avulsions although infrequent (Smith et al., 1989; Morozova and Smith, 2000) can best be studied by direct observation (Törnqvist, 1994; Mohrig et al., 2000).

The present study focuses on the lower Río Pastaza (Ecuadorian and northern Peruvian Amazonia) which drains one of the largest tropical alluvial megafan: the Pastaza Megafan (Räsänen et al., 1990 ; Bernal et al., 2011). Recently, substantial attention has been paid to the construction of the Pastaza Megafan (Christophoul et al., 2002; Bes de Berc et al., 2005; Burgos, 2006; Bernal et al., 2011). In the present study, an attempt is made to depict recent avulsions in the Lower Rio Pastaza, near its confluence with the Rio Marañon and to discuss their nature and their role in the construction of floodplain. This study is based on the analysis of the evolution of the fluvial morphology using satellital images and supported by the hydro-pluviometric data yet recorded in the region.

\section{2 - GEOLOGIC AND GEOMORPHOLOGIC CONTEXT}

The Río Pastaza drains the eastern Ecuadorian Andes and the upper Amazonian Basin (Fig.1). The Ecuadorian Andes are characterized by recently active volcanoes, two of them, the Tungurahua (5,020 m a.s.1.) and the Sangay $\left(5,230 \mathrm{~m}\right.$ a.s.1.) having had eruptions all through the $20^{\text {th }}$ century. Fluvial aggradation started in the Amazonian foreland around $22 \mathrm{Ma}$ with sediments derived from the west (Christophoul et al., 2002, Roddaz et al., 2005, 2010; Burgos, 2006). This sedimentation corresponds to the deposits of the Neogene Napo-Pastaza megafan sensu lato. The megafan apex migrated forward as a result of thrust fault propagation (Bès de Berc et al., 2005) but no tectonic influence has been detected in the study area except flexural subsidence origined as a result of thrust stacking in the cordilleras (Roddaz et al., 2005). The most recently active part of the Pastaza megafan (Räsänen et al., 1990; Räsänen et al., 1992; Zapata et al., 1998; Bernal et al., 2011) is located in the southeast of the Neogene megafan, in the subsiding area between the Pastaza - Marañon Ucayali confluence and the Iquitos Arch. The Rio Pastaza is $710 \mathrm{Km}$ long and its drainage basin covers $39,000 \mathrm{Km}^{2}$. The modern course of the Rio Pastaza in the Amazonian plain is the result of numerous avulsions (more than 100) which occurred since the Last Glacial Maximum (Bernal et al., 2011). The last major avulsion of the Rio Pastaza in the Amazonian plain is older than AD 1691 (Bernal et al. 2011).

\section{3 - THE RIO PASTAZA BASIN}

In the Amazonian foreland, the mean slope of the Rio Pastaza progressively decreases from $2.0 \mathrm{~m} / \mathrm{km}$ at its exits from the cordillera to $0,2 \mathrm{~m} / \mathrm{km}$ at its confluence with the Rio Marañon (Fig. 2). In the north, the Rio Pastaza forms a long $(125 \mathrm{~km})$ and smooth southward curve and the planform morphology changes from braided to low sinuosity single channel. (Fig. 2, reaches C and D).
In the south (Fig. 2, reach E), the Rio Pastaza preserves a main channel, a few metres higher than the flood plain, and several diverging single channels bifurcate from this main channel on both banks to re-join it downstream thus forming a typical anastomosed system.

\section{4 - HYDROMETEOROLOGICAL DATA}

A previous study of the pluviometry and discharge in Ecuadorian streams (Laraque et al., 2009) has shown that rainfall and discharge regimes are highly variable in space and show a strong orographical control. The pluviometric and hydrologic regimes of the Río Pastaza in various parts of its drainage basin have been established using data issued from three pluviometric and two hydrosedimentological stations (location on Fig. 2) over the period 1964-2005. The data issued from the station situated in the range (Cusubamba and Baños pluviometric stations, Baños hydrologic station) are highly dependant upon their situation. At the proximity of the study area, it is practically impossible to get any data because of isolation and insecurity (Laraque et al., 2009). In contrast, the stations of the middle Pastaza basin also situated in the Amazonian wetland can be considered to be representative of the lower Pastaza basin.

At the Teniente Lopez meteorological station (230 $\mathrm{m}$ a.s.1.), the average annual rainfall is $2,579 \mathrm{~mm}$ and is distributed roughly evenly throughout the year $(7-10 \%$ each month, Fig. 3). The minimum and maximum values of average monthly rainfall are $188.6 \mathrm{~mm}$ (March) and $252.8 \mathrm{~mm}$ (April), respectively (Espinoza et al., 2009). At the Andoas hydrological station (Fig. 2) $150 \mathrm{~km}$ upstream of the study area sediment discharge has been recorded for 5 years (1997-2002), with an average annual discharge of $910 \mathrm{~m}^{3} \mathrm{~s}^{-1}$. The highest average monthly discharge (Fig. 3) occurs in May $\left(1,222 \mathrm{~m}^{3} \mathrm{~s}^{-1}\right)$ and the lowest in September $\left(674 \mathrm{~m}^{3} \mathrm{~s}^{-1}\right)$.

Remote sensing analyses of the hydrology of the Amazonian wetland show that the lower Pastaza is like the rest of Amazonia affected by annual floods invading the whole floodplain. At high water stage, the floodplain entire of distal part of the Pastaza Megafan and as consequence, the lowermost Pastaza is covered by water (Mellack \& Hess, 2004; Martinez \& Le Toan, 2007). In contrast with the range and the immediate piedmont, we have no data showing the impact of ENSO events.

\section{5 - DATA AND METHODS}

\section{1 - Satellite images}

This study was based on the integration of available hydro-sedimentological and geological information with new morphologic and topographic data obtained from satellite and/or aerial images and a digital elevation model.

Spatial variations of channel pattern as well as avulsion occurrences were traced over the past 31 years using ASTER and Landsat time series satellite imagery (MSS, TM, ETM+, 1977-2002), and satellites CBERS (ChinaBrazil Earth Resources Satellite, 2008) for Ecuador-Peru. We selected the less cloudy images for approximately the 
same hydrological period (except the 2002 satellite image).

When necessary, the selected images were orthorectified using the software ENVI 4.2; and projected to UTM Zone $18 \mathrm{~S}$. The channel's vectors were digitized using the Geographic Information System (Arc View 9.1). However one of the main problems was the discrimination between open water and land. In order to solve this we used the wavelengths in the near and middle-infrared ranges $(740-2500 \mathrm{~nm}$; Jensen, 2000). However, the Andean piedmont remains very cloudy at any time and optical/IR image acquisitions remain uncertain, and the temporal coverage is weak. This supports the systematic use of SRTM images in spite their lower resolution.

\section{2 - Topographic data}

Topographic data used in this study are those of the SRTM-3 V4 DEM (Jarvis et al., 2008). Interest of SRTM3 data for geomorphological studies even in low relief areas have been shown by Coltelli et al, (1996), Farr et al., (2007) and Valeriano et al., (2007). These data are based on radar interferometry (INSAR) in $\mathrm{C}$ band. Pixel size at the equator is $90 \mathrm{~m}$ and slightly increases with the latitude. According to Rodriguez et al., (2005), error in height, in the studied part of the Amazonian lowland is $\sim 5 \mathrm{~m}$.

The SRTM DEM for our study area was reprocessed with ENVI 4.3 using elevation issued from topographic maps of the Ecuadorian and Peruvian geographic surveys. DEM SRTM V4 data are shown on Figure 4. In order to check the coherence of elevation data provided by the SRTMV4 DEM, we extracted a river long profile along the left bank of the main channel of the lowermost Pastaza (Fig. 5). Indeed, open water bodies provoke a loss of coherence in radar response and their elevation in the DEM results from interpolation with surrounding data. In the case of an alluvial river such as the lower Pastaza it should be reasonably assumed that river bank slope and river slope are similar, even though this is not necessarily the case in incising rivers. In fact, the slope computed from the elevation data is $0.25 \mathrm{~m} . \mathrm{km}^{-1}$ (Fig. 4) and that extracted from topographic maps is $0.2 \mathrm{~m} \cdot \mathrm{km}^{-1}$ (Fig. 2).

\section{6 - IMAGE AND TOPOGRAPHY ANALYSES}

Comparing satellite images allowed us to define three areas of interest along the lower Pastaza (Fig. 2 reach E). The first example is located in the right bank of the Rio Pastaza ( 1 on Fig. 5) and is concerned with opening of a channel joining the Rio Pastaza and one of its tributaries, the Rio Huangana. The second example is located downstream, to the left of the Rio Pastaza (2 on Fig. 5), and illustrates the evolution of a crevasse-splay into an anastomosed channel. The third example is an ancient crevasse splay more evolved than the preceding having given rise to a larger-scale anabranch downstream of the formers (3 on Fig. 5).

Despite the scarcity of cloud-free images 10 scenes showing a marked change in the fluvial morphology were found for the period 1977-2008 in the first example (Rio Pastaza- Rio Huangana junction) and 8 for the second. No optical images showing morphological changes have been found for the third example but this lack was supplied by a topographic analysis allowed by the SRTM DEM.

\section{1- The Rio Huangana crevasse-splay}

The initial image (1981/07/21) (Fig. 6) shows the Río Pastaza and the Río Huangana flowing almost parallel to each other. The Río Huangana is separated from the Pastaza by a large natural levee but will rejoin the Pastaza downstream. 1987/07/18 and 1989/07/23 images (Fig. 6) show a progressive diminution in the water flow of the Rio Huangana (Fig. 6). The July 1990 image (Fig. 6) shows a small diverging stream " $\mathrm{A}$ " issued from the outer bend of the Rio Pastaza and breaching the levee to join the Rio Huangana downstream.

The 1991, 1992 \& 1994 images (Fig. 6) show a slow but constant widening of the stream A. As a consequence, there is a considerable increase in water volume inducing the development of a crevasse-splay by the "A" channel (2001/06/30, Fig. 6) at the confluence with the Huangana, associated with the creation of a marsh between the Pastaza's western levee and the floodplain.. This marsh may have been a result of the formation of the crevasse splay damming the upper reach of the Huangana already situated at a lesser elevation than the Pastaza main channel). The 2008/02/01 image shows the Huangana River beheaded (Fig. 6). The distributive channels forming the crevasse-splay evolved into an anastomosing network rejoining the Rio Pastaza along the downstream course of the Rio Huangana.

\section{2 - Splay 2, left bank of the Rio Pastaza}

Figure 5.2 shows a $26.16 \mathrm{~km}^{2}$ large crevasse-splay made up of 3 lobes formed from 3 alluvial ridges. The 1981/07/21 image (Fig. 7) shows a well-developed crevasse-splay with a distributive network prograding into the floodplain. The July 1987, 1899 and 1990 images (Fig. 7), show these undefined flooded areas have disappeared and the trunk channel bifurcating downstream, leading to active channels organized in a classical distributary pattern. Only in 1990 (Fig. 7) the trunk channel joins the Pastaza. Between 1991 and 2008 the network becomes simpler with the progressive consolidation of a single trunk channel, which joins the Pastaza River downstream (Fig. 7).

The topography of this crevasse-splay is shown in figure 4. 4 transverse and 4 river/alluvial ridge long profiles were extracted from the DEM (Fig. 8). Profile 1 (Fig. 8) is close to the apex of the crevasse-splay and reveals a $1.7 \mathrm{~km}$ wide alluvial ridge culminating at $158 \mathrm{~m}$ a.s.l. above a low relief area with a mean elevation between 142 and $147 \mathrm{~m}$. Profile 2 (Fig. 8) is located in the area where the initial alluvial starts dividing into 2 and then 3 second order alluvial ridges. The ridge as a whole is now $2.9 \mathrm{~km}$ wide and culminates at $155 \mathrm{~m}$ a.s.l.. Profile 3 (Fig.8) exhibits the 3 second order ridges. Each of these ridges is around $1 \mathrm{~km}$ wide and culminate at $155 \mathrm{~m}$ a.s.l. Profile 4 crosses the two south-western lobes of the crevasse-splay which are wider $(2$ and $3.2 \mathrm{~km})$ and less 
elevated (147 and $149 \mathrm{~m}$ a.s.l.) than the upstream ridges whereas the floodplain is $136 \mathrm{~m}$ a.s.l. high. A V-shaped depression is observed between the eastern second order ridges. This depression is interpreted as the non-vegetated active channel (lighter green colour in the Landsat image, Fig. 5.2). A smaller but similar depression appears in the western second order ridge (profile 4, Fig. 8, left). This would indicate that the channels widen downstream within the alluvial ridges.

Profiles Lpl to Lp4 are long profiles of the alluvial ridges (Fig. 8). The upper enveloping line of the western more profile Lp1 shows a gentle downstream slope. This shape is globally concave up with a slope increasing downstream. The mean slope is $1.64 .10^{-3}$ that is an order of magnitude higher than the slope of the Rio Pastaza $\left(0.2 .10^{-3}\right.$, see fig.5A). Profile Lp2 is that of the central lobe of the crevasse-splay (Fig. 5). Its overall shape is similar to that of Lp1 and its mean slope is $1.22 .10^{-3}$. Profile Lp3 is that of the eastern lobe of the crevasse-splay. It is shorter than the other alluvial ridges of the splay $(2.3 \mathrm{~km})$ and has a steeper slope $\left(2 \cdot 07 \cdot 10^{-3}\right)$.

\section{3 - Splay 3, southern left bank of the Rio Pastaza}

This crevasse-splay (fig. 5.3) and its structure are difficult to identify on satellite images because of its low contrast, which suggests that vegetation is quite homogeneous and higher (darker) all over the splay. In contrast, the SRTM DEM reveals very clearly the structure (Fig. 4). 4 transverse topographic profiles (Profiles 5 to 8) and ridge long profiles (Lp4 to Lp8) are shown in Figure 9. Profiles 5 to 8 depict a proximal-distal gradient within the crevasse-splay. Profile 5 exhibits the same bell shape than profile 1 of Splay 2 and can similarly be interpreted as an alluvial ridge. The top of this alluvial ridge culminates at $157 \mathrm{~m}$ whereas the floodplain has an elevation of $136 \mathrm{~m}$. Profile 6 , located downstream in the crevasse-splay, enables the identification of two alluvial ridges. The first one is $5 \mathrm{~km}$ wide and culminates at 155 $\mathrm{m}$. The second is $1.7 \mathrm{~km}$ wide. Profile 7 is located still downstream and crosses only one alluvial ridge $2 \mathrm{~km}$ wide and $16 \mathrm{~m}$ high). The same alluvial ridge $1.2 \mathrm{~km}$ wide and $12 \mathrm{~m}$ high is visible in Profile 8 where another ridge is observed. The alluvial ridge long profiles (Lp4 to Lp8 on fig. 9) reveal the morphological characteristics of these splays. Profiles Lp4 and Lp5 (Fig.9) follow short transverse ridges $(\sim 3.5 \mathrm{Km})$ formed in the northern part of the splay (Fig. 5). These ridges are directly connected to the crevasse channel through the right bank levees of the Rio Pastaza main channel. They exhibit regularly decreasing slopes $\left(4.85 .10^{-3}\right.$ and $6.28 .10^{-3}$, respectively) toward the floodplain. This slope is an order of magnitude higher than the Pastaza river gradient $\left(0.25 .10^{-3}\right.$, Fig. 5). Lp6 (Fig. 9) shows the longest (longitudinal) alluvial ridge of the splay. The first $12 \mathrm{~km}$ of the profile exhibit a low but constant decrease in elevation with a $0.66 .10^{-3}$ slope followed by an abrupt decrease in elevation in the last kilometre. This decrease in elevation is interpreted as a vegetation change from the alluvial ridge to the floodplain. Lp7 and Lp8 are along longitudinal ridges/channels bifurcating from the Lp6 ridge/channel in the southern lobes of the splay. Lp7 is $3.8 \mathrm{~km}$ long. Its slope is $3.27 .10^{-}$ ${ }^{3}$. Lp8 is $5.5 \mathrm{~km}$ long and has a $1.24 .10^{-3}$ slope.

Satellite images reveal no evolution of the distributive drainage network of the crevasse-splay through time. This apparent stability of the drainage network along with the homogeneous vegetation suggest that this crevasse-splay is older than the other crevasse-splays described above and represents the terminal stage of evolution of a crevassesplay into an anastomosed channel. The older age of this crevasse splay may explain why Lp6 ridge/channel (fig. 9) has a lower slope than the other ridge/channels. It suggests that the anastomosed channel tries to reach an equilibrium profile with a regular slope by smoothing the knickpoint initially created at the jonction of the crevasse-splay distributary and the floodplain drain it annexes.

\section{8 - DISCUSSION}

\section{8-1 - History of avulsions}

All the 3 avulsion sets analysed involve crevasse splays showing the same evolutional trend: (1) initial crevassing; (2) crevasse splay propagation in the floodplain; (3) capture of one of the splay channels by a pre-existing channel of the floodplain (or annexation) with headward erosion progressively reducing the initial channel slope. Because headward incision diminishes the elevation of the captured splay channel, the flow of the other distributaries of the splay is captured into this channel (Fig. 10) (see also Smith et al., 1989; Slingerland and Smith, 2004). In our study area, this process will then arrive to the formation of a diverging - rejoining channel being part of a larger-scale anastomosing system.

In detail, the long profiles of the alluvial ridges indicate that an alluvial ridge evolved into an anastomosing channel after having acquired a lower slope than the others (Lp6 on Fig. 9 and in a lesser extend in Lp2 on Fig. 8). Slingerland and Smith (2004) propose that gradient decrease by headward erosion be associated with avulsions by incision and did not mention (but did not reject) this process for avulsions by progradation and annexation. In our cases, the difference in elevation between the floodplain and the ridge containing the avulsed channel will produce profile readjustment in any case. In fact, the systems studied experienced incision, annexation and progradation at various stages in their evolutional history. Splay 1 (Rio Huangana) started as an incising channel, then annexing a pre-existing river, and finally forming a prograding splay (beheading the host river) as a result of increasing flow and sedimentary load. Splay 2 initiates as a progradational splay with one of the distributive channels being then captured by (or annexing) a pre-existing small stream of the floodplain, implying incisional profile readjustment. Splay 3 likely initiated as a progradational splay, with a channel captured by (or annexing) a stream of the floodplain then affected by a strong incision. 


\section{2 - Origin of avulsions}

Set up and cause. The lower Pastaza flows in an area affected by flexural subsidence where aggradation rate is important. As for other highly aggrading alluvial rivers, the lower Pastaza main channel appears to be surelevated with respect to the floodplain, inducing a high ratio between channel-to-floodplain slope and channel slope (see Jones and Schumm, 1999). This channel is bounded by poorly vegetated levees. In the 3 cases we have observed that breaching of the levees occurred in the outer arc of meanders where the shear stress at the top of the levvees during flodds is maximum. This location seems to be at the origin of the rather regular anastomoses of the lower Pastaza on both sides of the main channel.

Trigger. In the studied area the seismic activity is reduced, log dams, vegetative blockages, animal trail are unlikely because of the size and high stream power of the river. Seismic fault surface rupture are also unlikely to occure in an area located far eastward from the subandean active faults. Floods are therefore the most likely triggers of avulsions. In our study area there are no evidences of exceptional floods related or not to ENSO events. In contrast, it has been shown that annual floods occur in this area as in the rest of the Amazonian wetland. It is therefore likely that annual floods triggered the avulsions. As reported by Jones and Schumm (1999), most of the observed avulsions are triggered by 'ordinary' floods provided that channel instability was close to the avulsion threshold. Meander outer arcs will constitute weakness zones in which crevassing and then avulsion will most easily occur. Aalto et al. (2003) pointed out the role of ENSO in the Amazonian Basin bringing great amount of water and sediment in amazonian rivers of Bolivia. Data presented in this sudy prevent us to correlate vrevassing and ENSO Event. Indeed, discharge data in Andoas hydrologic station do not cover the last significative ENSO Events. Moreover, satellite images cannot help us to show initial crevassing is related to ENSO events. The only case in which such event could have influenced the evolution of a crevasse splay would be the Rio Huangana. The development of the splay in the floodplain occurred between 1994 and 2001 (Fig.6). During this timerange, a sevre ENSO occurred in in the winter 1997-98.

\section{9 - CONCLUSION}

In spite of minor differences, the three examples studied in the present paper show the same evolutional history: (1) initial crevassing; (2) crevasse splay propagation in the floodplain; (3) capture of one of the splay channels by a pre-existing channel of the floodplain with headward erosion progressively reducing the initial channel slope; (4) change of this channel into a diverging - rejoining channel being part of a larger-scale anastomosing system. The main difference is concerned with the capturing (or annexed) floodplain stream. In example 1 (Rio Huangana) this stream is a tributary flowing parallel to the main channel for a rather long distance before being annexed and beheaded. The splay is rather distant from the main channel, relatively small, and immediately postdates the annexation. In examples 2 and 3 , the splay forms where crevassing occur, is relatively large, and develops a distributary network. Capture or annexation selects one of these drains to further become an anabranch of the future larger-scale anastomosing system. Crevassing and consecutive avulsions take advantage of the presence of meanders and this location seems to be at the origin of the rather regular anastomoses of the lower Pastaza.

Although the precipitation regime and discharges curves are rather regular, levees breaching and crevasse splay formation are likely to be results of annual floods which are present in this area as in the rest of Amazonia.

\section{Acknowledgments}

This investigation was supported by a doctoral Albon fellowship of the European Union ( $n^{\circ}$ E05D057404EC), IRD and Université Paul Sabatier grants. We are grateful to the HYBAM/Ecuador project and its partnership institutions, INAMHI and IRD; and to the 'Instituto Geofisico' of the 'Escuela Politecnica Nacional' of Quito-Ecuador. The authors thank Centre for Tropical Agriculture (CIAT) for providing topographic data through $\underline{\mathrm{http}}: / /$ srtm.csi.cgiar.org

\section{REFERENCES}

Aalto R, Maurice-Bourgoin L, Dunne T, Montgomery DR, Nittrouer C, Guyot J-L (2003) Episodic sediment accumulation on Amazonian floodplains influenced by El Niño/Southern Oscillation. Nature, 425:493-497.

Assine, M., 2005. River avulsions on the Taquari megafan, Pantanal wetland, Brazil. Geomorphology, 70: 357-371.

Bernal C., Christophoul, F., Darrozes, J., Soula, J-C., Baby, P., Burgos, J., 2011. Late glacial and holocene avulsions of the Rio Pastaza Megafan (Ecuador-Peru): Frequency and controlling factors. International Journal of Earth Sciences (Geologische Rundschau), 100, 1759-1782, doi 10.1007/s00531-010-0555-9.

Bès De Berc, S. Soula J, Baby, P., Souris, M., Christophoul, F., Rosero, J., 2005. Geomorphic evidence of active deformation and uplift in a modern continental wedge-top-foredeep transition: Example of the eastern Ecuadorian Andes, Tectonophysics, 399: 351- 380.

Bridge, J., 2003. Rivers and Floodplains: Forms, Processes and Sedimentary Record. Blackwell Publishing. 491p.

Burgos, J., 2006. Genese et progradation d'un cone alluvial au front d'une chaine active: example des Andes Equatoriennes au Neogene. Unpublished Ph.D. Thesis, Université Paul Sabatier, Toulouse, France, 282p.

Coltelli, M., G. Fornaro, G. Franceschetti, R. Lanari, M. Migliaccio, J. R. Moreira, K. P. Papathanassiou, G. Puglisi, D. Riccio, and M. Schwabisch, 1996. SIR-C/X-SAR multifrequency multipass interferometry: A new tool for geological interpretation, Journal of Geophysical Research, 101: 23127-23148.

Espinoza J.C., Ronchail J., Guyot J.L., Cochonneau G., Filizola N., Lavado W., de Oliveira E., Pombosa R., Vauchel P., 2009. Spatiotemporal rainfall variability in the Amazon Basin Countries (Brazil, Peru, Bolivia, Colombia and Ecuador). International Journal of Climatology, 29: 1574-1594.

Farr, T. G., et al. (2007), The Shuttle Radar Topography Mission, Review of Geophysics, 45, RG2004, doi:10.1029/2005RG000183.

Jain, V. \& Sinha, R., 2005. Response of active tectonics on the alluvial Baghmati River, Himalayan foreland basin, eastern India. Geomorphology, 70: $339-356$.

Jarvis, A., H.I. Reuter, A. Nelson, E. Guevara, 2008, Hole-filled seamless SRTM data V4, International Centre for Tropical Agriculture (CIAT), available from http://srtm.csi.cgiar.org.

Jensen, J. R., 2000. Remote Sensing of the Environment: An Earth Resource Respective. Prentice Hall, Upper Saddle River, New Jersey.

Jerolmack, D.J., Paola, C., 2007, Complexity in a cellular model of river avulsion, Geomorphology, doi:10.1016/j.geomorph.2007.04.022. 
Jones, L., Harper, J., 1998. Channel avulsions and related processes, and large - scale sedimentation patterns, Rio Grande, San Luis Valley, Colorado. Geological Society of America Bulletin, 110: 411-421.

Jones, L., Schumm, S. 1999. Causes of avulsion: an overview. Special Publication of the International Association of Sedimentologists, 28: 171-178.

Laraque, A., Bernal, I.C., Bourrel, L., Darrozes, F., Christophoul, F., Armijos, E., Fraizy, P., Pombosa, R., Guyot, J-L., 2009. Sediment budget of the Napo river (Amazon basin, Ecuador and Peru). Hydrological Processes, 23: 3509-3524.

Leier, A., DeCelles, P. and Pelletier, J., 2005. Mountains, monsoons and megafans, Geology, 33: 289- 292.

Makaske, B., 2001. Anastomosing rivers: a review of their classification, origin and sementary products. Earth Science Reviews, 53: 149-196.

Martinez, J.M., Le Toan, T., 2007. Mapping of flood dynamics and spatial distribution of vegetation in the Amazon floodplain using multitemporal SAR data. Remote Sensing of Environment, 108: 209223.

Mellack, J.M., Hess, L.L., 2004. Remote sensing of wetlands on a global scale. SIL News, $42: 1-5$

Mohrig, D., Heller, P.L., Paola, C., Lyons W.J., 2000. Interpreting avulsion process from ancient alluvial sequences: GuadalopeMatarranya (Northern Spain) and Wasatch Formation (western Colorado), Geological Society of America Bulletin. 112: 1787-1803.

Morozova, G., Smith, N., 2000. Holocene avulsion style and sedimentation patterns of the Saskatchewan River, Cumberland Marshes, Canada. Sedimentary Geology, 13: 81-105

Räsänen, M.E., Salo J.S., Jungnert H., Pittman L.R., 1990. Evolution of the Western Amazon Lowland Relief : impact of Andean foreland dynamics. Terra Nova, $2: 320-332$

Räsänen, M.E., Neller, R., Salo, J. \& Jungner, H., 1992. Recent and ancient fluvial deposition systems in the Amazonian foreland basin. Peru Geological Magazine. 129 : 293-306.

Roddaz, M., Baby, P., Brusset, S., Hermoza, W., Darrozes, J., 2005. Forebulge dynamics and environmental control in Western Amazonia: The case study of the Arch of Iquitos (Peru). Tectonophysics, 399: 87-108.
Roddaz, M., Hermoza, W., Mora, A., Baby, P., Parra, M., Christophoul, F., Brusset, S., Espurt, N., 2010. Cenozoic sedimentary evolution of the amazonian foreland basin system, in Hoorn, C., and Wesselingh, F., Amazonia, Landscape and species evolution: a look in the past. Blackwell Publishing, ISBN: 978-1-4051-8113-6, 61-88.

Rodriguez, E., C.S. Morris, J.E. Belz, E.C. Chapin, J.M. Martin, W. Daffer, S. Hensley, 2005. An assessment of the SRTM topographic products, Technical Report JPL D-31639, Jet Propulsion Laboratory, Pasadena, California, 143 pp.

Sarma, J., 2005. Fluvial process and morphology of the Brahmaputra River in Assam, India. Geomorphology, 70: 226 - 256.

Sinha, R, Jain, V., Prasad Babu, G. and Ghosh, S., 2005. Geomorphic characterization and diversity of the rivers of the Gangetic plains Geomorphology, 70, 207-225.

Smith, N.D., Cross, T.A., Dufficy, J.P., Clough, S.R., 1989. Anatomy of an avulsion. Sedimentology, 36: 1-23.

Slingerland, R. and Smith, N.D., 2004. River avulsion and their deposits. Annual Review of Earth and Planetary Sciences. 32: 257 -285.

Stanistreet, I.G., Cairncross, B, McCarthy, T.S., 1993. Low sinuosity meandering river bedload rivers of the Okavongo Fan: channel confinment by vegetated levées without fine sediment. Sedimentary Geology, 85:135-156.

Stouthamer, E. and Berendsen, H.J.A., 2000. Factors Controlling the Holocene Avulsion History of The Rhine- Meuse Delta (The Netherlands). Journal of Sedimentary Research, 70 : 1051-1064.

Stouthamer, E. and Berendsen, H.J.A., 2007. Avulsion: The relative roles of autogenic and allogenic processes. Sedimentary Geology, 198 : 309-325.

Törnqvist, T.E., 1994. Middle and Late Holocene avulsion history of the River Rhine (Rhine-Meuse delta, Netherlands), Geology ,22: 711 714.

Valeriano, M.M., Kuplich, T.M., Storino, M., Amaral, B.D., Mendes JR. and Lima, D., 2006. Modeling small watersheds in Brazilian Amazônia with SRTM-90m data. Computer in Geosciences, 32: 1169-1181.

Zapata, A., Ticona, P., \& Atencio, E., 1998. Evolución del Abanico del Pastaza y su relación con los depósitos Ucamara, X Congreso Peruano de Geología, Lima - Perú, 61-70. 


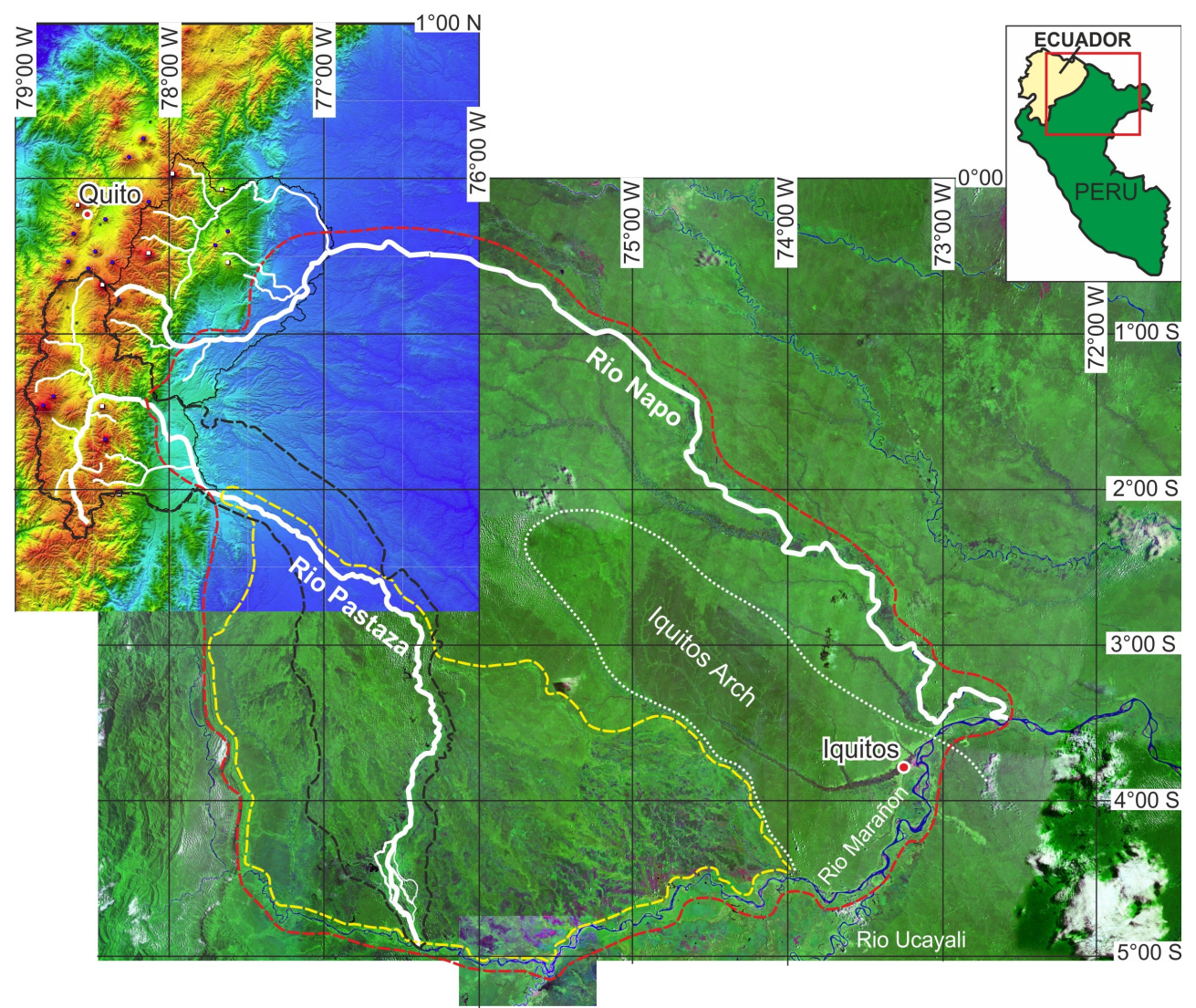

Figure 1-Mosaic of Digital Numeric Model of Napo-Pastaza Megafan. The watershed is represented in black lines and the modern river network, in white. White squares represent active volcanoes (Reventador Volcano, RV; Tungurahua Volcano, TV; Sangay Volcano, SV) and blue spots represents active volcanoes. Black dashed line: boundary of the rio pastaza river basin. Red dashed line is the boundary of the NapoPastaza megafan (Bes de Berc et al., 2005). Yellow dashed line represents the post-LGM Pastaza Megafan (Bernal et al., 2011).

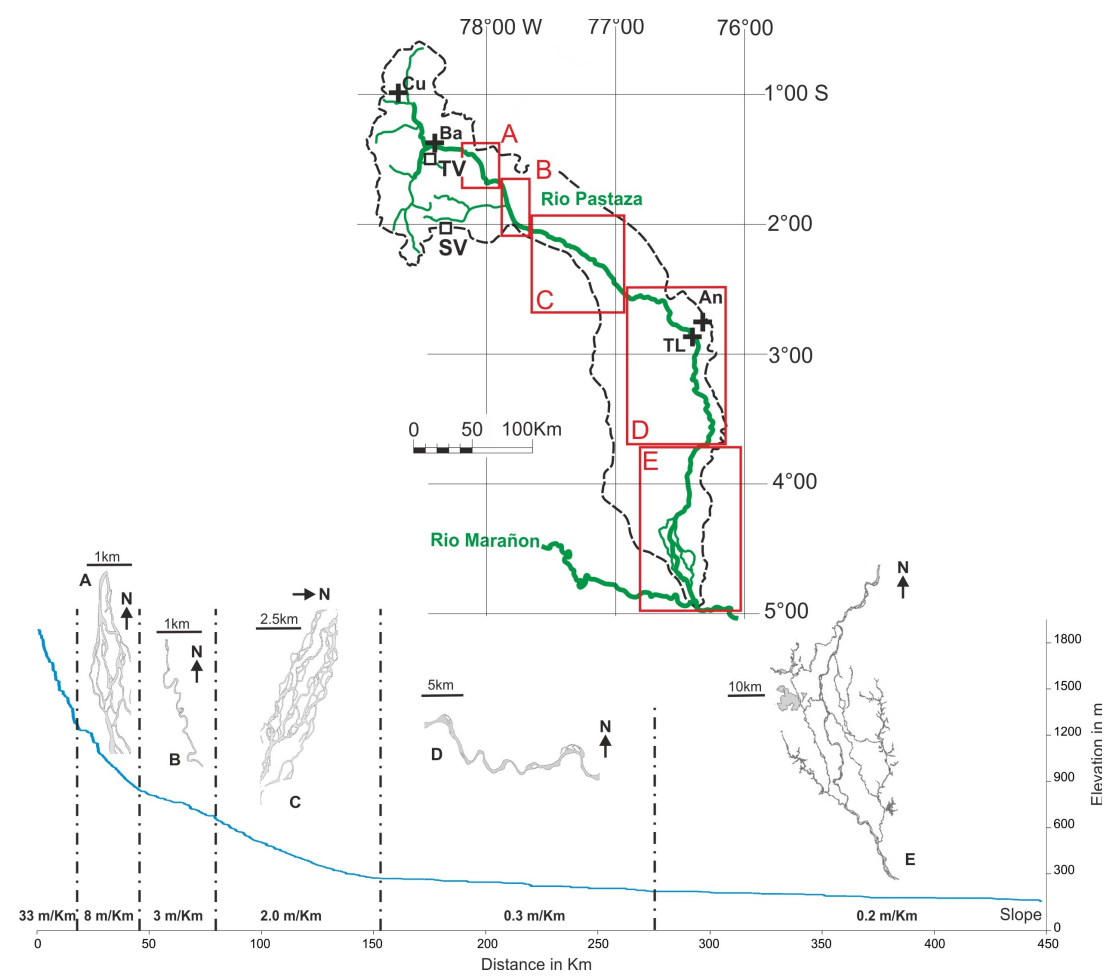

Figure 2-The Rio Pastaza: drainage basin, hypsometric profile of the Rio Pastaza and associated channel patterns (reaches A to E). White squares: active volcanoes with TV: Tungurahua and SV: Sangay. Black crosses: (Cusubamba St., Cu; Baños St., Ba; Andoas St., An; Teniente López St., TL). 


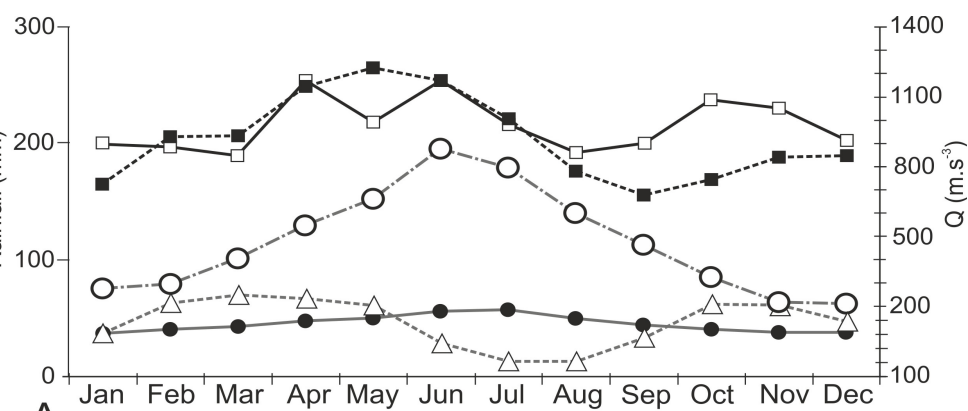

A basin. (A) Monthly average rainfall is represented by an empty symbol ( $\mathrm{mm})$. 200 Meanwhile, a monthly average discharge $(Q)$ is represented by a filled symbol $\left(\mathrm{m}^{3} \cdot \mathrm{s}^{-1}\right)$. Modified $\overline{\overline{\mathrm{\sigma}}}$ from Laraque et al., 2009. White triangles: Rainfall at Cusubamba station, white spots: $\llbracket 100$ discharge at Baños station, white spots: rainfall at baños station, white squares: rainfall ay Teniente Lopez station, black squares: discharge at Andoas Station. (B) Daily hydrographs (in $\left.m^{3} \cdot s^{-1}\right)$ at the Baños gauging station.
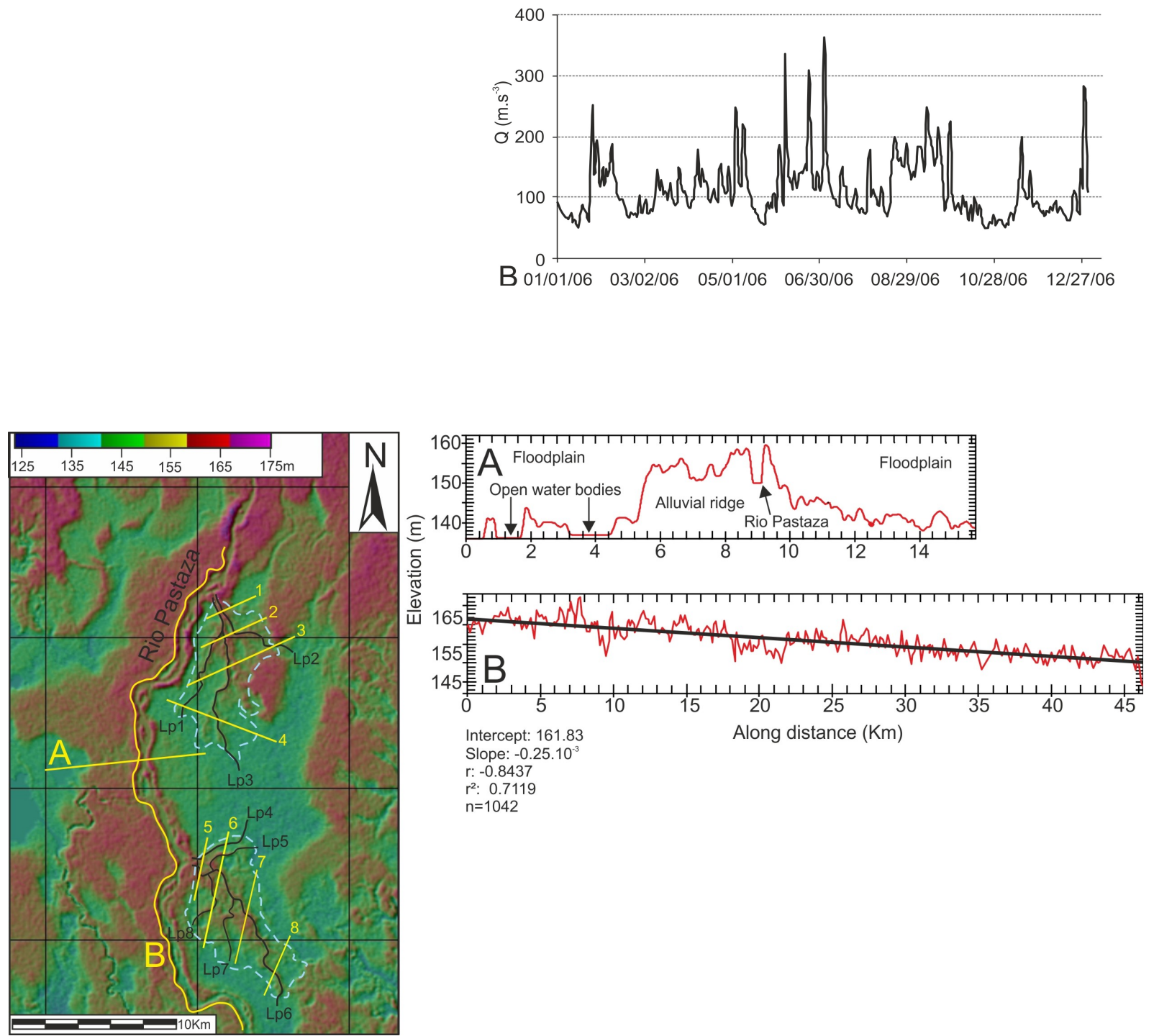

Figure 4-SRTM V4 DEM of the lower Rio Pastaza and topographic profiles. This DEM shows the topography of the Modern Rio Pastaza alluvial ridge and its associated floodplain. On the left bank of the Rio Pastaza, two crevasse-splays can be observed. The correspond respectively to the crevasse-splay 2 and 3 on Figure 3. The crevasse-splays are bounded by a light blue dashed lines. Yellow solid lines 1 to 8 and black solid lines Lp1 to Lp6 corresponds to the topographic profiles exhibited on figures 8 and 9. A and B: topographic profiles with A: topographic profile across the Rio Pastaza alluvial ridge, and B: topographic profile of the Rio Pastaza alluvial ridge extracted along the Rio Pastaza right bank. 

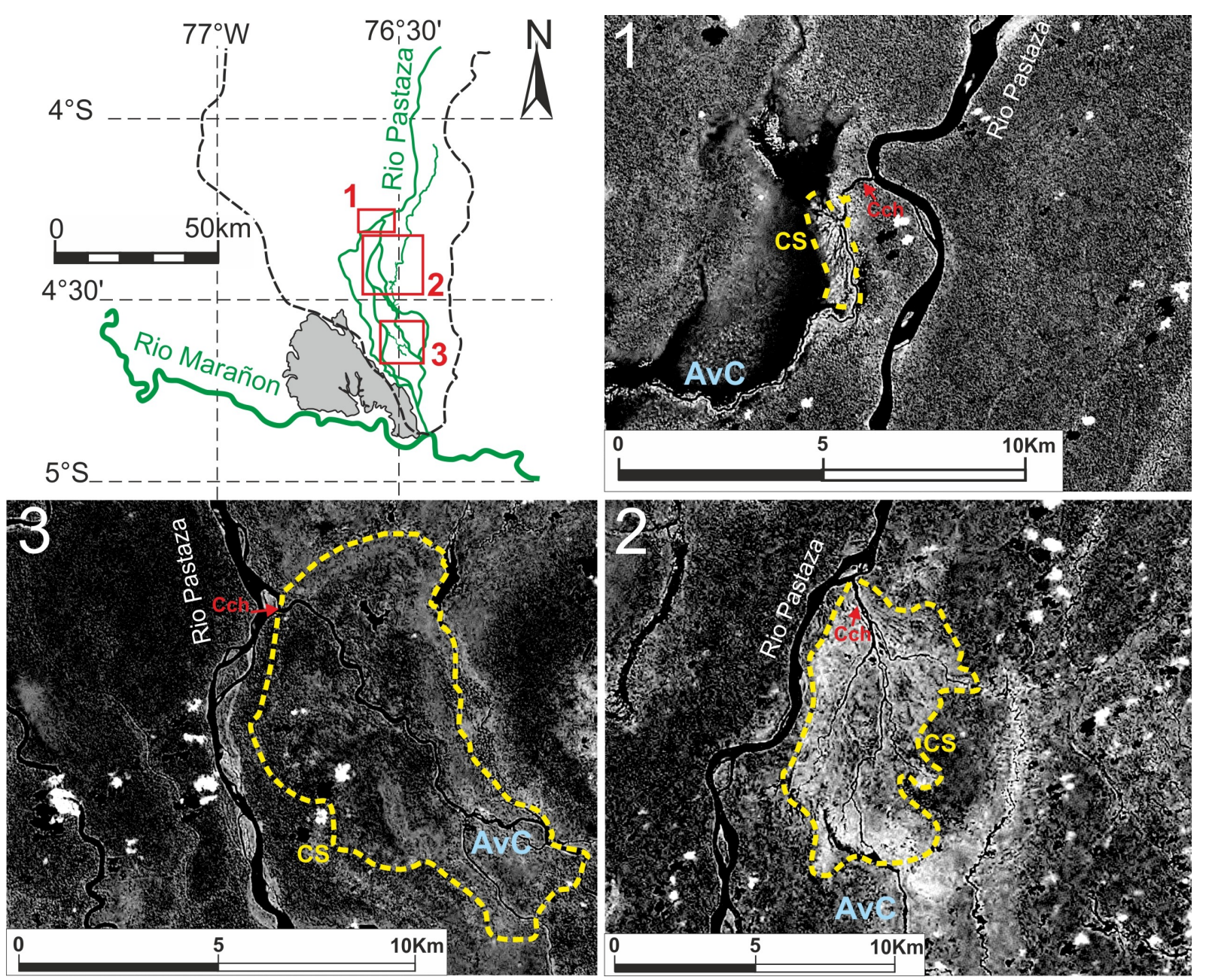

Figure 5 -Location and satellite images of the 3 crevasses splays and anastomosing channels detailed in this study (Landsat TM, VNIR band). Black dashed line: boundary of the Rio Napo drainage basin, green solid line: active channels. 1) Rio Huangana crevasse-splay, 2) Splay 2, left bank of the Rio Pastaza, 3) Splay 3, Southern left bank of the rio Pastza. Yellow dashed line: boundary of crevasse-splays. CS: crevasse-splay, CCh: Crevasse Channel, AvC: Anastomosing channel. 


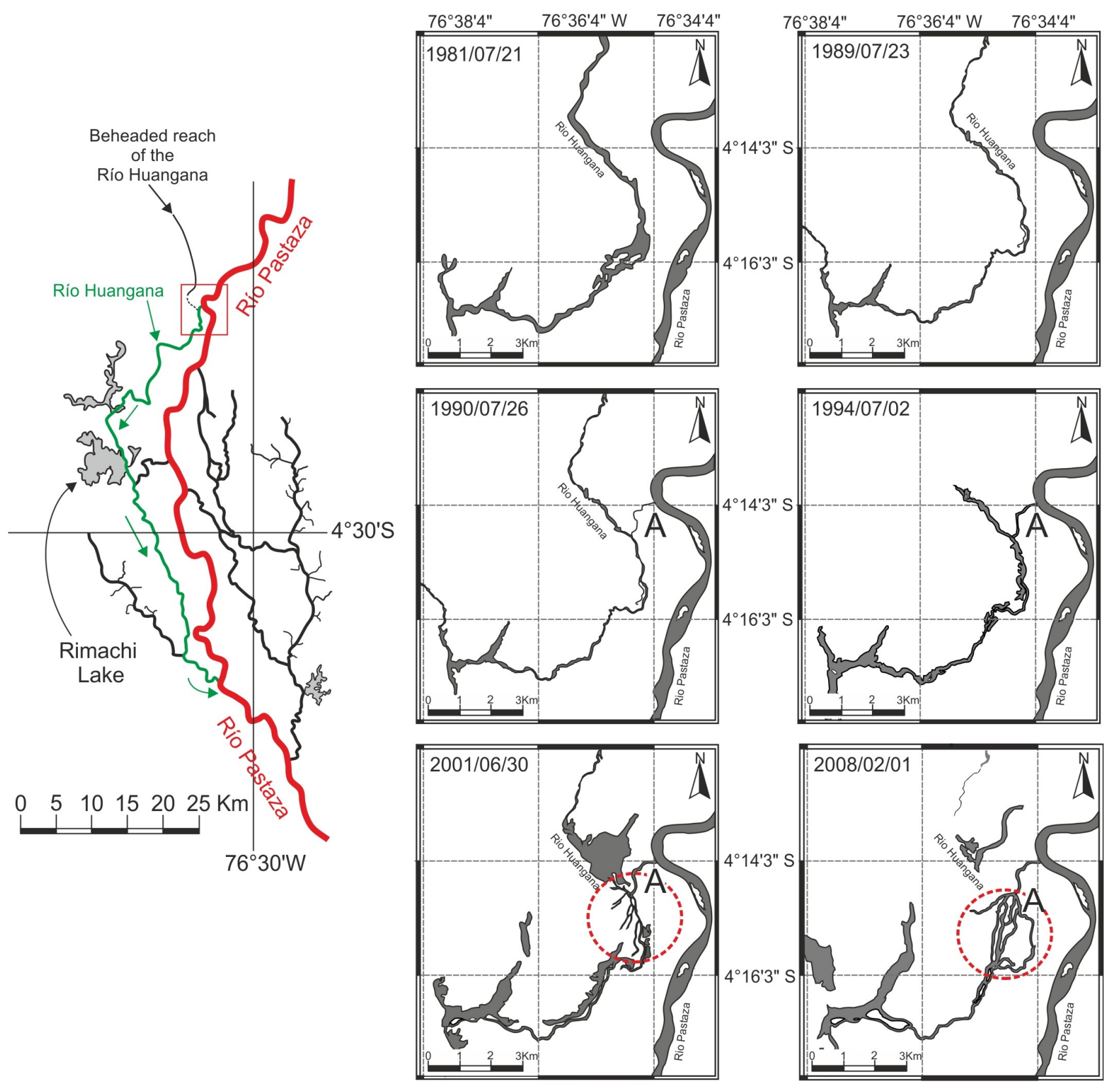

Figure 6 - Time series of satellite images (Band 5 - Landsat \& Band 4 - CBER) recording the avulsion and crevasse-splay evolution of the Rio Huangana crevasse-splay on the right bank of the Rio Pastaza. On the left: map of the lowermost Rio Pastaza, exhibiting the Rio Huangana, its point of divergence with the Rio Pastaza (red box) illustrated by the time series on the right. Remark the downstream junction of the Rio Huangana with the Rio Pastaza through the Rimachi floodplain lake. 


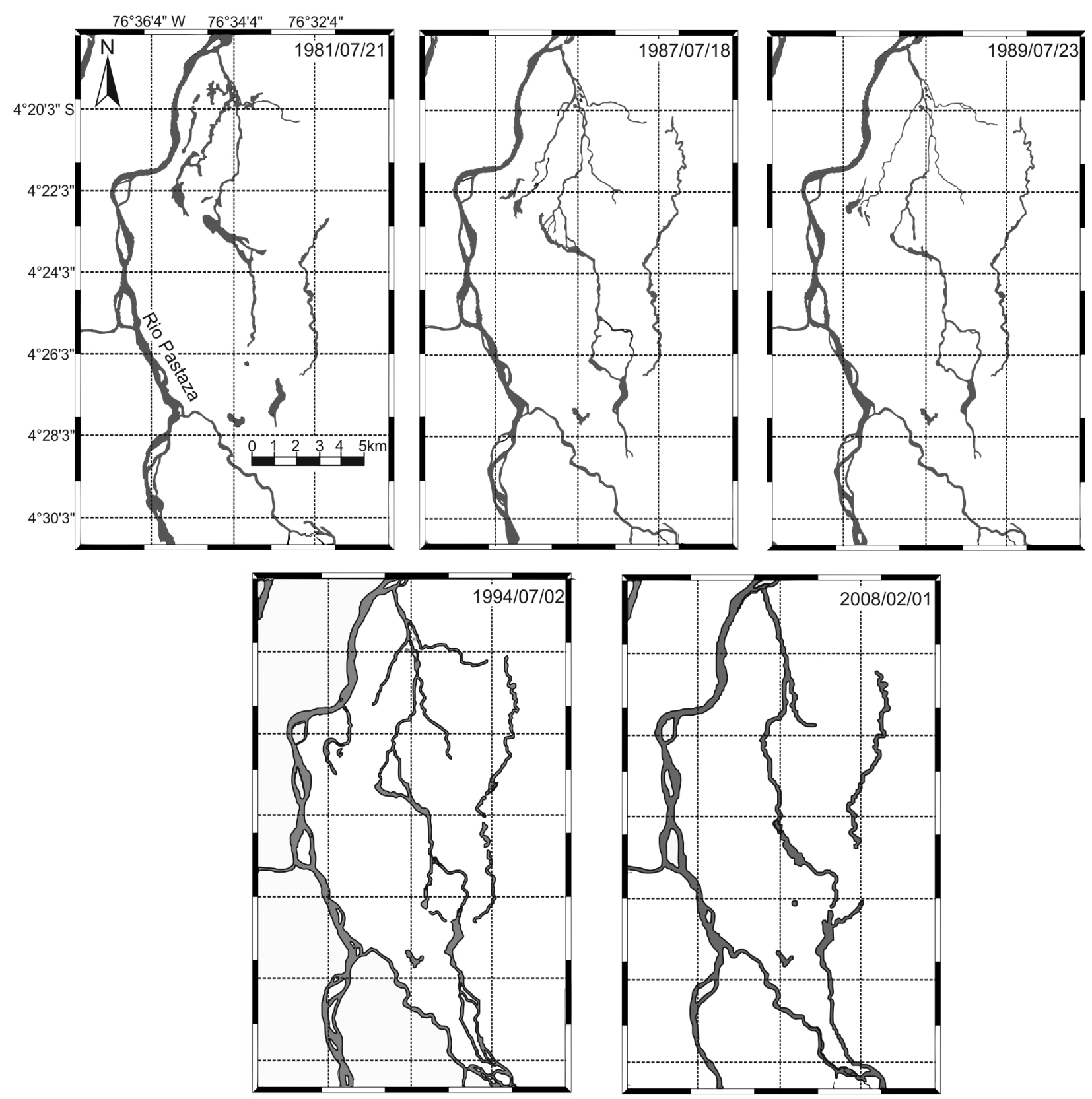

Figure 7 -Time series of satellite images (Band 5 - Landsat \& Band 4 - CBER) recording the avulsion evolution and crevasse-splay evolution of the Splay 2 on the northern left bank of the Rio Pastaza. 
Figure 8 - Topographic profiles of the Splay 2 on the northern left bank crevasse-splay. Location of profiles on figure 5. Profiles 1 to 4: topography across the crevasse-splay. Profiles Lp1 to Lp3: river long profiles of the alluvial ridge of the crevasse-splay.
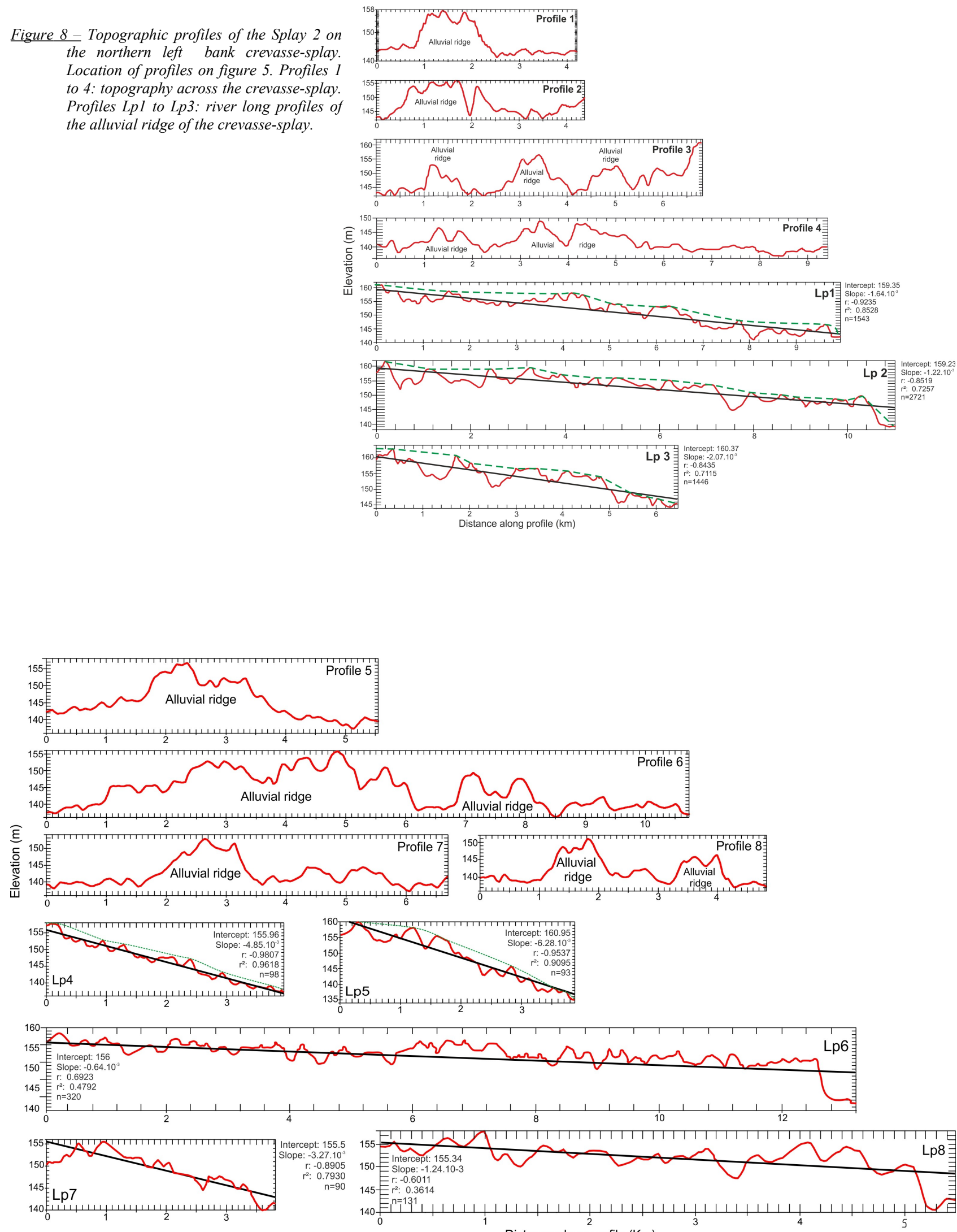

Distance along profile $(\mathrm{Km})$

Figure 9-Topographic profiles of the Splay 3, on the southern left bank crevasse-splay. Location of profiles on figure 5. Profiles 5 to 8: topography across the crevasse-splay. Profiles Lp4 to Lp8: river long profiles of the alluvial ridge of the crevasse-splay. 

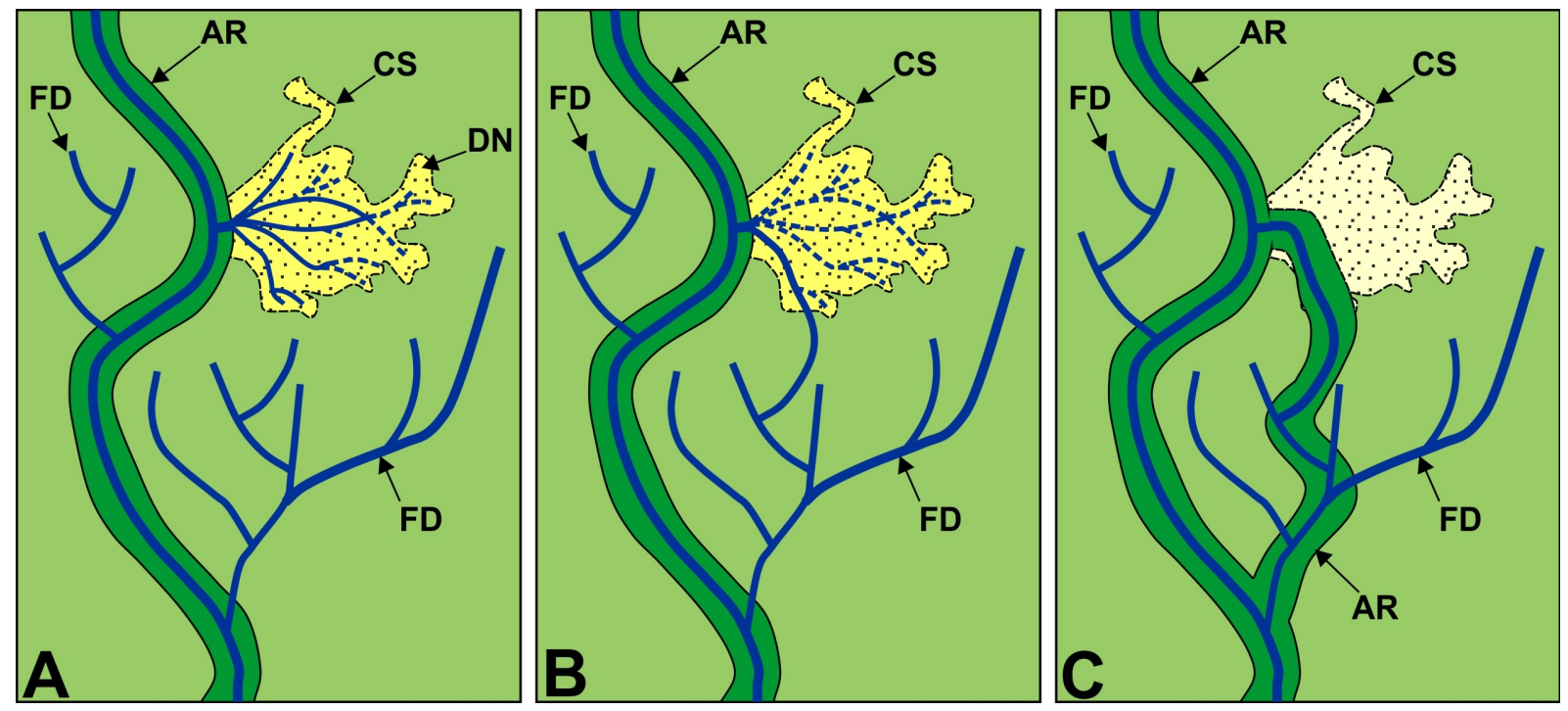

Figure 10 - Sketch map showing the evolution of the lower Pastaza crevasse-splay into an anastomosing alluvial ridge. AR: Alluvial ridge (including channel and natural levees), CS: crevasse-splay, DN: Distributary network, FD: Floodplain drainage. A: initial crevassing and progradation of the crevasse-splay in the floddplain. B: crevasse-splay channel capture by a pre-existing floodplain drain and abandonment of the crevase splay channel after the capture. C: final abandonment of the crevasse-splay channels end development of a new alluvial ridge joining the former crevasse-splay drain upstream and the former floodplain drain downstream. 